\title{
Analysis on the Spatial Distribution of Knowledge-intensive Services Trade in China and Its Influencing Factors
}

\section{Lei Chen}

Business College, Huanggang Normal University, Huanggang, Hubei, 438000, China Email: chenlei19830921@126.com

\begin{abstract}
Knowledge-intensive services trade as the core of knowledge, technology and its application is becoming the most important part and competition hot in the international services trade, which has accounted for a large proportion of its total trade. In this paper, the method of factor analysis is used to analyze the influencing factors of the spatial distribution of China's knowledge-intensive service trade. It's concluded that human capital and the use of foreign capital is the main influencing factors, and the corresponding countermeasures are proposed, which is of great significance for promoting development of knowledge-intensive services industry in China and enhancing export competitiveness.
\end{abstract}

Keywords: knowledge-intensive services trade, spatial distribution, influencing factors, factor analysis

\section{Introduction}

At present, knowledge-intensive industries have become an important driving force in the development of world economy, the level of development of knowledge-intensive industries not only determines a country's international competitiveness, but also determine the status of international division of labor in which a country is in the world economy. Chi- na's knowledge-intensive services trade is closely related to the development of knowledge-intensive industries. To some extent, the high level of development of knowledge-intensive industries in an area, the higher level of knowledge-intensive services trade in the region. In addition, knowledge-intensive services trade is also closely related with the geographical features.

\section{Index system construction of influ- encing factors of knowledge- intensive services trade space dis- tribution}

\subsection{The meaning of knowledge- intensive services trade and space distribution in China}

Knowledge-intensive services trade refers to that domestic services providers provide foreign consumers with interactive and innovative service products with higher level of knowledge and technology through commercial presence or movement of natural persons, while obtaining corresponding income for business activities, and knowledge-intensive services trade is divided into several items such as communication services, construction services, insurance services, financial services, computer and information services, royalties and license fees, advertising and consulting, cultural and recreational services. 
From the import and export of China's trade in services in the provinces, the eastern provinces have become the major regions of the import and export of services trade. In 2009, the total import and export volume of trade in services in Shanghai, Beijing, Guangdong Province, Tianjin and Jiangsu ranked top five in the country. Import and export trade in services in Shanghai totaled $\$ 74.732$ billion, accounting for $26.1 \%$ of the proportion of the country, import and export trade in services in Beijing totaled \$ 64.41 billion, accounting for $22.5 \%$ of the proportion of the country, Guangdong Province, import and export trade in services totaled 42.95 billion U.S. dollars, accounting for $15 \%$ of the proportion of the country, import and export trade in services in Tianjin achieved a total of 14.406 billion U.S. dollars, accounting for $5 \%$ of the proportion of the country, Jiangsu Province, import and export trade in services achieved a total of $\$ 16.784$ billion, accounting for $5.8 \%$ of the proportion of the country. The total exports and imports services trade of the five provinces accounted for $74.4 \%$ of the proportion of the total import and export volume of trade in services all over the country. Compared with the eastern regions, trade in services in the central and western regions is still at a low level.

\subsection{Construction of Index System}

A core element in the development of knowledge-intensive services trade is intelligence-intensive capital, that is to say, advanced technology and creative talents become a key factor to support the development of knowledge-intensive services trade. In addition, the level of the development of knowledge-intensive industry in a region is closely related to the extent of the development of regional knowledge-intensive services trade. The more developed knowledge-intensive industries in a region and the stronger competitiveness in exports, it will have a greater advantage than the same kind of industry in other areas.

\subsubsection{R \& D input indicators}

Research and development input indicators include investment in research and human resources. Investment in research is mainly reflected in the $\mathrm{R} \& \mathrm{D}$ funding the government and related units invested in, we have chosen R \& D / GDP to indicate the strength of the research activities, and it reflects the size of the strength of investment in research in an area for a while.

Human resource input indicators selection should fully show the level of knowledge structure of the human resources and the ability to innovate. We select the proportion of researchers and the proportion of college education labor on behalf of the human resource input indicators, which reflects the level of quality of the human resources investment.

\subsubsection{R \& D output indicators}

$\mathrm{R} \& \mathrm{D}$ output indicators are able to reflect innovation of the knowledge and technology and product innovation. It includes the patent, the National Science and Technology Award and so on. The number of patent is one of the commonly used indicators to measure regional innovation capacity, which can reflect the amount of knowledge innovation in the region from a certain angle, comparing the knowledge and technology innovation capability and industrial structure between different regions to some extent. Therefore, taking into account the availability of data, the article selects the number of national patents and the tertiary sector share of GDP to reflect R \& D output indicators. 


\subsubsection{Regional openness index}

Regional openness index is mainly involved in the intensity of the opening up of the region. In terms of finance, the opening up of the region directly have impact on capital formation and changes, and contribute to the accumulation of the capital of the region; from the perspective of human resources, for the talent, the greater opening up of the area to the outside, the more increasing flow of the talent. It is conducive to the inflow of the talents through regional preferential policies. The article introduces foreign direct investment share of GDP to measure the opening up of the area to the outside.

\subsubsection{Regional economic development level indicators}

Economic development level of the region can be measured by a per capita GDP and per capita consumption level, and the level of economic development of the region determines the level of development of the region's services industry.

\begin{tabular}{|l|l|l|}
\hline \multirow{2}{*}{$\begin{array}{l}\text { R \& D input } \\
\text { indicators }\end{array}$} & $\begin{array}{l}\text { variable } \\
\text { name }\end{array}$ & connotation \\
\cline { 2 - 3 } & $\mathrm{X} 1$ & R\&D/GDP \\
\cline { 2 - 3 } & $\mathrm{X} 3$ & $\begin{array}{l}\text { the proportion of } \\
\text { college education } \\
\text { labor }\end{array}$ \\
\hline $\begin{array}{l}\text { proportion of re- } \\
\text { searchers }\end{array}$ \\
\hline $\begin{array}{l}\text { R \& D out- } \\
\text { put indica- } \\
\text { tors }\end{array}$ & Y1 & $\begin{array}{l}\text { number of nation- } \\
\text { al patents }\end{array}$ \\
\cline { 2 - 3 } $\begin{array}{l}\text { Regional } \\
\text { openness } \\
\text { index }\end{array}$ & Z1 & $\begin{array}{l}\text { the tertiary sector } \\
\text { share of GDP }\end{array}$ \\
\hline $\begin{array}{l}\text { Regional } \\
\text { economic } \\
\text { development } \\
\text { level indica- } \\
\text { tors }\end{array}$ & R1 & $\begin{array}{l}\text { foreign direct in- } \\
\text { vestment share of }\end{array}$ \\
\cline { 2 - 3 } & R2 & $\begin{array}{l}\text { per capita con- } \\
\text { sumption level }\end{array}$ \\
\hline
\end{tabular}

Fig. 1: Indicators system

\subsection{Data sources and method choice}

\subsubsection{Data sources}

According to the statistics above, transportation services trade data in the provinces of our country and other business services data can not be obtained, so the specific volume of knowledgeintensive services trade in the provinces of China can not be calculated. Therefore, the article selected the top ten regions where the trade in services in 2009 in the country ranked in the country as a sample of the knowledge-intensive services trade areas to conduct a study to analyze the factors that affect the regional distribution of knowledge-intensive service trade. Based on the evaluation index system of knowledge-intensive services trade influencing factors established by Table 2 in this article, the relevant data is gathered and organized from the "China City Statistical Yearbook 2010", "Shanghai Statistical Yearbook 2010", "Beijing Statistical Yearbook 2010", "Hebei Economic Yearbook 2010", "the sixth census" as well as the National Bureau of Statistics website authoritative data dissemination agencies.

\subsubsection{Choice of method}

As above, we select the related indicators of the ten regions to study the factors of the spatial distribution of the knowledge-intensive services trade, which is a multiregional, multi-index model, the intricate relationship may exist between the variables of these indicators, when it's required to extract from the few variables and it also requires these variables not to be relevant to each other as much as possible. We select the factor analysis method to establish model in 
order to make these influencing factors clear.

\begin{tabular}{|c|c|c|c|c|c|c|c|c|c|c|}
\hline region & & $\mathbf{N}$ & $\mathrm{x} 3$ & & Y2 & & $\mathrm{R} 1$ & R2 & FACl_I & \\
\hline Shanghai & 2.81 & 21.95 & 0.75 & 34913 & 59.36 & 6.33 & 78989 & 29572 & 1.1824 & \\
\hline Beijing & & & & 921 & 38 & & 80452 & 154 & 2.32035 & \\
\hline Tianjin & 2.37 & 17.48 & 0.13 & 20515 & 45.27 & & 62574 & 15149 & 0.20663 & \\
\hline langdong & 1.41 & 8.21 & 0.64 & 83621 & 45.72 & 8.16 & 41166 & 15291 & $\begin{array}{l}.33249 \\
\end{array}$ & 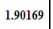 \\
\hline Jiangsu & 2.03 & 10.81 & 0.87 & 87268 & 39.55 & 0.23 & 19169 & 11993 & 0.51644 & 554 \\
\hline Zhejiang & 1.75 & 9. & 0.0 & 945 & 43.1. & & 4464 & 5291 & 0.38001 & 0541 \\
\hline Shandong & 1.53 & 8.69 & 0.39 & 34513 & 34.72 & 4 & 35894 & 10494 & -0.62225 & \\
\hline Fujian & 1.11 & & 0.36 & & 41.26 & & 38840 & 10950 & -0.56367 & .6931. \\
\hline , thoung & 1.53 & & & & & & 35239 & 10848 & -0.41198 . & \\
\hline & 0. & & & 1839 & 35.21 & 1.57 & 24581 & 193 & 0.8825 & \\
\hline
\end{tabular}

Fig. 2: Component score in each region

\section{Construction of the model}

SPSS software is utilized to make factor analysis of the above data, the following results were obtained:

The "total variance" explained variance explained by each common component and its cumulative summation. We observed the cumulative $\%$ column under the "initial feature value" column, two common components that explain the cumulative variance have reached more than $85 \%$, and so extracting two common components can better explain the original variables including the information.

Component loadings are the correlation coefficient of each variable and the common component, for a variable, larger loadings' absolute value of the component has closer relationship with it, and also more representative of the variable. According to the view, the first common component represents the proportion of the number of the highly educated and R \& D investment, the second common component represents the proportion of foreign direct investment share of GDP. Through further analysis, the first common component can be explained for human re- sources component, because it reflects the elements associated with the human capital, and the second common component can be explained for the utilization of foreign capital.

According to the table 2, it can be seen that the first component scores highest in Shanghai and Beijing, which shows that these two regions have an absolute advantage in human capital factor; In Shanghai and Guangdong Province, the second component scores highest, which reflects that these two regions have outstanding performance in attracting foreign capital investment. Therefore, it is concluded that the spatial distribution of the knowledge-intensive services trade is mainly related to the elements of human capital and the use of foreign elements.

\section{Conclusions}

(1) Optimize the urban investment environment, attract domestic and foreign investment into the industry of specific high-end service sector, such as high-end finance industry, which provides a good external environment for the development of knowledge-intensive service industries, and the development of knowledgeintensive service industries will further promote knowledge-intensive services trade exports. When the region formulates development strategies of the knowledge-intensive service sector, it should dovetail with its own industrial layout and urban layout structure to find the combination point of knowledgeintensive service sector and urban space industry structure optimization. Form a rational planning of urban infrastructure, population distribution planning, functional area planning to protect the development of the knowledge-intensive service industries, make the development of the knowledge-intensive services trade 
mutually promoted with the development of the city.

(2) Build up a group of knowledgeintensive service talent, which is an important support for the development of knowledge-intensive service sector. The local government should introduce policies to increase the talent of high-end service sector in shortage introduction and the strength of training, and establish the human resources repository of knowledge-intensive service. First, introduce the knowledge-intensive service personnel at home and abroad through a variety of ways, such as relaxing the restriction of access to knowledge-intensive service personnel household registration, creating knowledge-intensive personnel live and work environment, establishing and developing the international professional talent agency and broadening the channels to attract talent. Then accelerate the development of knowledge-intensive service talent through a variety of specific ways, such as guiding institutions of higher learning and social training institutions to develop knowledge-intensive services professional education at different levels and types, cultivating and developing much-needed talent of knowledge-intensive service sector through different channels and forms.

\section{References}

[1] Weijiang, Taoyan, Wanglin. "Research on the concept and classification of knowledge-intensive service sector", China Soft Science, iss. 1, pp. 33-41, 2007.

[2] Wangtieshan. "The connotation, effect and development tendency of the knowledge-intensive services trade", International Trade, iss. 6, pp. 19-24, 2009.

[3] Niuduanduan. "Empirical Research on Structure and Competitiveness of Knowledge-intensive Services Indus- try", Forum on Science and Technology in China, iss. 8, pp. 48-53, 2009.

[4] Panjing. "Empirical Study of the Effects of China's Knowledge-based Trade in Service on the Economic Growth", Journal of Dalian University of Technology, iss. 4, pp. 12-17, 2010.

[5] Lilei, Zhaoxu. "Analysis on characteristics of tertiary industry development in China", Economics Information, iss. 12, pp. 34-38, 2006.

[6] Jiangxiaojuan, Peichanghong. "China's Service Industry Development Report No.3", China Social Sciences Press, pp. 89-108, 2005. 